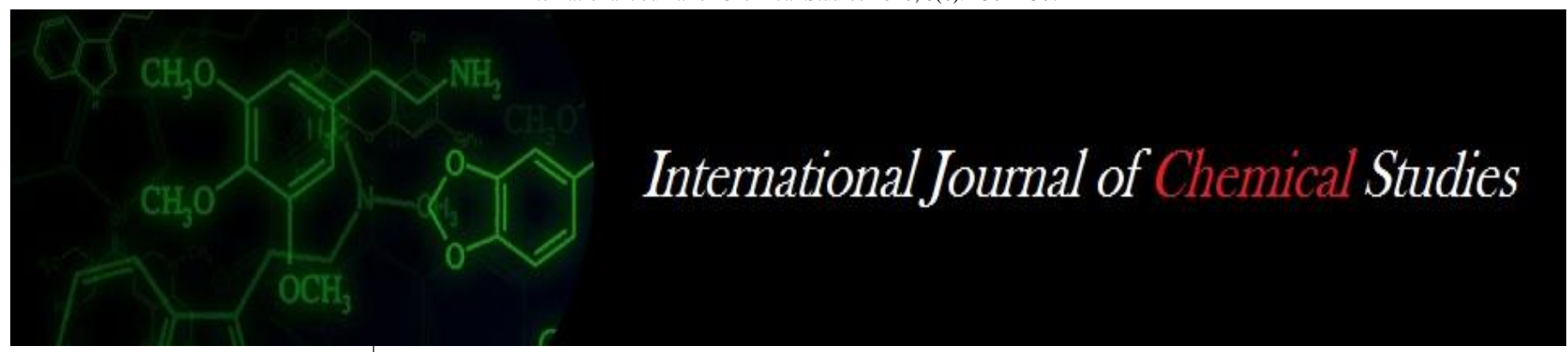

P-ISSN: 2349-8528

E-ISSN: 2321-4902

www.chemijournal.com

IJCS 2020; 8(6): 2302-2307

(C) 2020 IJCS

Received: 17-09-2020

Accepted: 23-11-2020

Dhani Reddy Suma Sree M.Sc. Research Scholar, Department of Agronomy, School of Agriculture, Lovely Professional University, Jalandhar, Punjab, India

Corresponding Author: Dhani Reddy Suma Sree M.Sc. Research Scholar, Department of Agronomy, School of Agriculture, Lovely Professional University, Jalandhar, Punjab, India

\section{Role of sulphur in pulse crops: A review}

\author{
Dhani Reddy Suma Sree
}

DOI: $\underline{\text { https://doi.org/10.22271/chemi.2020.v8.i6ag.11119 }}$

\begin{abstract}
Sulphur is essential nutrient for every living cell; it is component of 21 amino acids which form protein. It is fourth key plant nutrient after nitrogen, phosphorus and potassium. Pulses are particularly sensitive to sulphur deficiency which gives low quality and less yields. sulphur plays a key role In chlorophyll and oil synthesis. Plants uptake sulphur only in sulphate form $\left(\mathrm{so}_{4}^{2-}\right)$ and it reduces to form sulphur containing amino acids and other compounds. Application of sulphur increases the nitrogen use. Efficiency of $\mathrm{N}, \mathrm{P}, \mathrm{K}$ is seriously affected under sulphur deficiency. Field experiments in many agro climatic conditions shown that application of 30 and $40 \mathrm{~kg} \mathrm{~S} / \mathrm{ha}^{-1}$ along with recommended dose given the highest yields and protein content in pulses. Moreover, this review highlights the availability of sulphur for profitable crop production, effects of different sources and levels of sulphur in pulse crops, effect of sulphur on various parameters and it also includes the sulphur absorption and translocation in plants. Moreover this review provides new sights to revisit the sulphur significance in pulse crops.
\end{abstract}

Keywords: Sulphur, protein, pulses, assimilation, deficiency, levels, sources and fertilizer

\section{Introduction}

Pulses are the main source of protein in Indian diet. Pulses are consumed as a Dal, which is a cheap source of plant protein. These are consumed because of their body building properties, presence of various amino acids. Pulses also have medicinal properties. Byproducts of pulses like pods, leaves, pod coats, bran are given to animals in the form of dry fodder. Some crops like Lobia, Gram, urdbean \& Moongbean are fed to animals as green fodder. Moong plant are also used as green manure which improve soil health and it adds nutrients to the soil. A number of pulse crops are grown in India and the world. Among them major ones are Gram, Chickpea, Lentil, Field peas etc. The steady increase in the population taken together with the stagnant production of pulses over decades resulted in insufficiency in calories and imbalance in nutritional supply. The current per capita availability of pulses is about 48 grams this was decreased from previous years (statista research department, october 16, 2020).

Sulphur is essential macro nutrient required for the plant growth and development of plants. Sulphur in agricultural soils have important concern for the agriculturists all over the world because they are mostly negative, due to the decline of sulphur levels in the soil have been changed to strict environmental rules on industrial emissions. (Lewandowska M, Sirko A., 2008) ${ }^{[28]}$ Sulphur is attaining importance in all the regions of the world because of frequent sulphur deficiencies in time and space several factors contributing to sulphur deficiencies were reported by many researches includes, the increased use of sulphur free high analysis fertilizers, and less use of sulphur containing pesticides along with multiple and high intensive cropping, no use of organic manures (Shivay YS, Prasad R, Pal M., 2014) ${ }^{[42]}$. leaching and erosion and sulphur containing pesticides (McNeill AM, Eriksen J, Bergström L, Smith KA, Marstorp H, Kirchmann H, Nilsson I., 2005) ${ }^{[30]}$. Restricted use of Sulphur is recognized as fourth major plant nutrient after Nitrogen, phosphorous and potassium and it plays important role in many plant process like metabolisam which is dependent upon sulphur and its deficiency causes primary metabolic impairment. In plants sulphur concentrations are found to be lower than nitrogen (Saito K et al., 2004) ${ }^{[40]}$. It is similar to that of phosphorus (Ali A, Arshadullah M, Hyder SI, Mahmood., IA., 2012). In all crops general pulses and oilseeds, sulphur is found in many different oxidation states in nature $\mathrm{i}$ : e, inorganic, organic and bioorganic forms but plants uptake sulphur mainly in the inorganic sulphate from the soil. Sulphur deficiency is found in all over the world including India. Tripati N. et al., (2003) ${ }^{[53]}$ 
reported that atleast 57 million ha out of 142 million ha of ariable land is deficient in sulphur and this causes heavy loss in crop yield due to its role in metabolism. Sulphur stress affects metabolic and physiological activities of plants, it also affects the carbohydrate (sugar and starch) metabolism. In sulphur deficient crops sugars were decreased and starch was accumulated in leaves. Sulphur is a constituent of essential compounds i: e, cysteine, methionine, several coenzymes (Biotin, coenzyme A, Thiamine Pyrophosphate and lipolic acid), thioredoxins, and sulpholipids. Cyestine is required for the synthesis of protein and glutathione (GSH) synthesis or functions as a sulphur donar for methionine and secondary metabolite biosynthesis. Glutathione helps to control the concentration of reactive oxygen species (ROS) and participates in the regulation of sulfate uptake and in the detoxification of heavy metals.

\section{Sulphur chemistry in soil}

Sulphur present in rocks is in the form of sulfide (Metamorphic and igneous), in soil it occurs in combination with organic matter, it is also present in oceans, industrial wastes, and as gaseous form in the atmosphere. Hence sulphur is present in soil in both organic and inorganic forms. Amount of inorganic and organic sulphur depends upon soil $\mathrm{pH}$, texture, organic matter calcium carbonate and other soil characteristics (Dhamak AL, Meshram NA, Waikar SL., 2014) ${ }^{[12]}$. Out of many inorganic forms of sulphur, sulphide, elemental sulphur, sulphate etc. sulphate form of sulphur is available to the plants for their growth and development. Indian soils contains about $30 \%$ of total sulphur in organic combination in alluvial soils where as in Mollisols of tarai region it reaches to $70 \%$ (Singh SK, Dey P, Latare AM, Singh S, Sharma PK, Singh CM, Singh YV, Kumar., 2015) ${ }^{[46]}$. Sulphur is deficient in highly weathered soils like (Oxisols and Ultisols) (Sabir M, Hanafi MM, Hakeem KR., 2015) ${ }^{[39]}$. Sulphur precipitation is found in the form of sodium sulphate or calcium, magnesium. In marshy lands we can see the accumulation of pyrites in large amounts in the form of sulphide metals (Havlin JL, Beaton JD, Tisdale SL, Nelson WL., 2005) ${ }^{[21]}$. Sulphur balance in soil and plant system is based on plant uptake, volatilization, and mineralization. sulphur requirement varies with the crops. It is generally in the order of Cruciferae > Leguminosae > Poaceae. (Table-1) (Lucheta AR, Lambais MR., 2012) ${ }^{[29]}$. For producing one ton seed of pulses we require $8 \mathrm{~kg}$ of sulphur (Jamal A, Moon YS, Abdin MZ., 2010) ${ }^{[26]}$.

Table 1: Pulse crop demand for sulphur in different agro-climatic conditions.

\begin{tabular}{|c|c|c|c|c|c|}
\hline S. No & Crop & $\begin{array}{c}\text { Sulphur } \\
\text { Requirement }\end{array}$ & Agro-climatic conditions and location & Soil & Reference \\
\hline 1. & Black gram & $40 \mathrm{~kg} \mathrm{ha}^{-1}$ & $\begin{array}{c}\text { Humid subtropical } \\
\text { (Kumarganj, Faizabad) }\end{array}$ & Sandy loam & Niraj VPS, Prakash V., $2014{ }^{[34]}$. \\
\hline 2. & Soya bean & $40 \mathrm{~kg} \mathrm{ha}^{-1}$ & $\begin{array}{l}\text { Humid subtropical } \\
\text { (Ambikapur) }\end{array}$ & Sandy loam & Paliwal AK, Vajpai SK, Vajpai K., \\
\hline 3. & Mung bean & $45 \mathrm{~kg} \mathrm{ha}^{-1}$ & $\begin{array}{l}\text { Humid subtropical } \\
\text { (Varanasi) }\end{array}$ & $\begin{array}{l}\text { Sandy clay loam } \\
\text { (Inceptisol) }\end{array}$ & Tripathi PK, Singh MK, Singh JP, Singh, 2012 \\
\hline 4. & Soya bean & $40 \mathrm{~kg} \mathrm{ha}^{-1}$ & $\begin{array}{l}\text { Tropical wet and dry } \\
\text { (Dharwad) }\end{array}$ & Vertisol & $\begin{array}{l}\text { Hosmath JA, Basavaraj GT, Agasimani, SC, } \\
\text { Jahagirdar S, Babalad HB, Athoni BK, } 2014\end{array}$ \\
\hline 5. & Pigeon pea & $20 \mathrm{~kg} \mathrm{ha}^{-1}$ & Subtropical (Nagpur) & Dark clay & $\begin{array}{c}\text { Deshbhratar PB, Singh PK, Jambhulkar } \\
\text { AP, Ramteke DS., 2010 }\end{array}$ \\
\hline 6. & Soya bean & $20 \mathrm{~kg} \mathrm{ha}^{-1}$ & $\begin{array}{l}\text { Tropical wet and dry } \\
\text { (Hyderabad) }\end{array}$ & Sandy loam & $\begin{array}{c}\text { Anil D, Sagar GCV, Sreenivas G, Sharma } \\
\text { SHK., } 2017^{[3]} \text {. }\end{array}$ \\
\hline 7. & Sun hemp & $40 \mathrm{~kg} \mathrm{ha}^{-1}$ & $\begin{array}{c}\text { Subtropical } \\
\text { (Pratapgarh, UP) }\end{array}$ & $\begin{array}{l}\text { Sandy loam } \\
\text { (Inceptisol) }\end{array}$ & $\begin{array}{c}\text { Saha S, Saha M, Saha AR, Mitra S, Sarkar } \\
\text { SK, Ghorai AK, Tripathi MK.,2013 }{ }^{[41]} \text {. }\end{array}$ \\
\hline
\end{tabular}

\section{Absorption and translocation of sulphur}

Sulphur is an essential plant nutrient taken up by the plants as $\mathrm{S}_{\mathrm{O} 4}{ }^{2-}$ form from the soil, it is reduced and incorporated into the plant cells as bioorganic compounds. Hermsen C, et al (2010) ${ }^{[22]}$ reported that conduit of $\mathrm{SO}_{4}{ }^{2-}$ assimilation is regulated in demand determined manner in seed plants. Autotrophic plants have a set of transporters and enzymes that referee to uptake and absorption of $\mathrm{SO}_{4}{ }^{2-}$ and exchange into organic sulphur compounds. Hell and Hillebrand, (2001) ${ }^{[20]}$ reveled that availability of sulphur promotes growth and development of higher plants. SULTRI 3, a high affinity transporter is localized to the phloem and mediate long expanse translocation from roots (source organs) followed by leaves and shoots (sinks) (Yoshimoto et al., 2003) ${ }^{[57]}$. Yield and quality of legume seeds are decrease by the quantity of sulphur partition to the seeds. The amino acid S-methyl methionine (SMM), a methionine lacking in originality and a long-distance transport form of condensed Sulphur and whether SMM phloem load and source-sink translocation are significant for the growth and metabolism of pea (Pisum sativum) plants.

\section{Sulphur deficiency in different regions}

In India 135,000 soil samples reveled that $42.3 \%$ samples are deficient in available sulphur and 300 districts are suffering from sulphur deficiency as compared to 70 districts (Tandon HLS et al., 2010) ${ }^{[50]}$. Soils of semi -arid tropical regions severe conditions may be noticed and eastern gangetic plains of the country (Singh SK, Sharma PK, Dey P, Singh YV, Latare AM, Singh CM, Singh S, Kumar D, Kumar O, Yadav SN, Verma SS., 2015) ${ }^{[46]}$. Singh and Sonu Kumar (2012) ${ }^{[44]}$ reveled that in pulse growing upland red soils deficiency is comparatively high $(92.0 \%)$ than Black soils $(37.0 \%)$ and alluvial soils (48.0\%). In India crop removal of sulphur is to be estimated as $1.26 \mathrm{Mt}$, but recovery through fertilizers is only about $0.76 \mathrm{Mt}$. (Tiwari KN, Gupta BR., 2006) ${ }^{[52]}$

\section{Effect of sulphur on various parameters}

Sulphur limitation in pulse crops showed reduced growth and photosynthetic rates (Giordano et al., 2000) ${ }^{[18]}$. Adverse effect on sulphur deficiency on biochemical process and inorganic nutrition may led to the reduce in the growth and lastly may effect in decline in the yield of the chickpea (Badruddin and Karmoker, 2001) ${ }^{[6]}$. Sulphur limitation showed strong reduction in photosynthesis and it correlate with a substantial decline of chlorophyll $\mathrm{a} / \mathrm{b}$ binding protein and rubisco (Jamal, 2006) ${ }^{[25]}$. Sulphur deficient plants give lower yield and have a reduced nutritional value. Sulphur 
deficiency severely affects activity of photosynthesis. The chlorophyll content was condensed because of universal decline of PSII and PSI and the related light harvesting antenna. In sulphur deprived plants Rubisco content was significantly decreased. The imbalance between carbon fixation and photosynthesis, and between PSII and PSI led to broad decrease of the photosynthetic electron carriers chromatographic investigation results show that level of starch substance was advanced and level of monosaccharide's was lower in the sulphur deprived plants. while there are no changes in the metabolite levels were observed in the calvin cycle or TCA (Lunde et al., 2009). Sulphur is an essential macro nutrient that accelerates the plant growth (Thomas et al., 2000). Sulphur content resulted optimistic effect on seed yield and its value is important and visible, when sulphur substance is near to the ground in soil (Ahmad et al., 2007; Malhi et al., 2007). Due to the deficiency of sulphur, biological nitrogen fixation, nodulation and yield of peanut crops are decreased. Varin et al., (2010) ${ }^{[55]}$ showed whether the outcome of sulphate adding on nitrogen fixation resulted from a stimulus of host plant growth, a definite affect of sulphur on nodule metabolism or nodulation due to the application of sulphate form of sulphur there is an increase in whole plant dry mass, nodule biomass and root length, expressed on a root length basis. Nitrogen fixation was significantly reduced in sulphur scarce plants because of a low nodule expansion but also due to low nitrogenase and leghaemoglobin production.

\section{Importance of sulphur in pulse cropping}

Sulphur is a divisive chemical factor (Ostowska et al., 2008). The concentration of sulphur was found to be highest in oil seed $(1.1-1.7 \%)$, followed by pulses $(0.24-0.32 \%)$ and the least $(0.12-0.20 \%)$ in cereals (Singh, 2001). It is linked with nitrogen metabolisam and its application increases the nitrogen uptake by the plants (Mondal MMA, Badruddin M, Malek MA, Hossain Mb, Puteh AB., 2012) ${ }^{[33]}$. Visual sulphur deficiency symptoms include chlorosis on young leaves and reduced plant growth (stunted growth, thin and woody stem, reduced leaf size, premature defoliation etc.) and its toxicity symptoms include intervenal necrosis, chlorosis, mottling in young leaves, bluish green appearance of older leaves, bushy appearance of lateral branches (Chandra N, Pandey N., 2016) ${ }^{[10]}$. It causes the acidification of atmosphere on one hand, on other hand it is a required constituent of amino acids e.g. cysteine and methionine, which is a mandatory for protein production essential for growth and biomass. It is classify as a secondary nutrient which is obligatory for all plants for the development and metabolism (Vidyalakshmi et al., 2009) ${ }^{[56]}$. Sulphur has a amount of oxidising function in plant nutrition and is a constituent of Fe-S proteins called Ferridoxin, which is responsible for transfer of electrons in the photosynthesis (light dependent) reactions during its first phase (Randall,

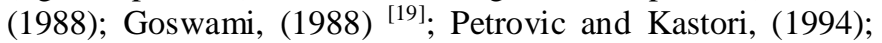
Marschner, (1995)). Sulphur has a thoughtful effect on create absorption area gripping PAR and as an outcome on yield of the crops. with the function of $\mathrm{S}$ up to $20 \mathrm{~kg} / \mathrm{ha}$ has significantly increased the total number of nodules and active nodules (Ganeshamurthy and Readly, 2000) ${ }^{[16]}$. Varin et al. (2010) ${ }^{[55]}$ experimental the result of sulphate addition on nitrogen fixation resulted from a encouragement of host plant growth, a definite effect of Sulphur on nodule metabolism or a definite effect of Sulphur on nodulation. In black gram, relevance of gypsum at the rate of $60 \mathrm{Kg} / \mathrm{ha}$ considerably results advanced pod length, seed/pod to 1000 seed weight and function of $20 \mathrm{~kg} \mathrm{~S} / \mathrm{ha}$ also extensively increased the dry matters yield of soya bean (Ganeshamurthy and Reddy, 2000) [16]

\section{Interaction of sulphur and nitrogen in soil and plant}

Intensive agricultural practices with the use of high analysis fertilizers and improved cultivars offers the exhaustion which results in nutrient difference in soil. Fazili et al., (2008) experimental that require of sulphur limits the effectiveness of added $\mathrm{N}$, so it is essential to add sulphur in soil to attain maximum competence of applied nitrogenous fertilizer. Sulphur and nitrogen play a central role in the combination of proteins, these nutrients are highly inter-related. sulphur and nitrogen relatives were report in many studies. (Jamal et al.,2005; 2006a; 2010) ${ }^{[24,25,26]}$.

\section{Effects of sources of sulphur in pulses}

Anil Kumar Patel, Triyuginath, Anurag prajapati, Vivek Kumar Singh. (2018) ${ }^{[4]}$ reported that field experiment to evaluate the effect of different level and sources of sulphur on growth and yield of Black gram. Sulpur sources viz; gypsum, elemental sulphur and ammonium sulphate were used at different levels 0, 20, 40 and $60 \mathrm{~kg} / \mathrm{ha}$. Application of Zypsum 40kg S/ha recorded highest growth (plant height, leaf area index, dry matter production and number of branches per plant), yield components (no of pods/plant and no of seeds/pod) and yield (grain and hulm) in black gram. R. RS. Sodiya et al. (2016) ${ }^{[38]}$ conducted a pot experiment to examine the effects of different sources of sulphur (cosawet, gypsum, bentonite and elemental sulphur) on kharif ground nut with sulphur sources viz; 0, 5, 10, 15, $20 \mathrm{mg}$ sulphur/kg. In this experiment application of bentonite sulphur $20 \mathrm{mg} / \mathrm{kg}$ produced significantly. The highest $\mathrm{K}$ content $(0.568 \%)$ at 60 DAS as compared to remaining doses of sulphur. Moni sankar Bera and Gautam Kumar Gosh (2012) conducted experiment on sulphur source in green gram viz; Zypsum, Magnesium sulphate and single super phosphate and levels of sulphur 0 , $20,40,60$ and $80 \mathrm{~kg} \mathrm{~S} / \mathrm{ha}$, maximum seed yield was obtained with Single super phosphate and magnesium sulphate @ 60kg S followed by gypsum. N. C. Banik and K. Sen Gupta (2012) conducted an experiment with different sulphur sources and levels they have obtained highest seed yield by applying 30 $\mathrm{kg}$ SSP along with recommended dose. S. P. singh, Yogesh Kumar and Sonu Singh (2012) ${ }^{[44]}$ conducted experiment on different sources and levels of sulphur in green gram, results reveled that plant height, branches per plant, nodules per plant and test weight was found maximum with $40 \mathrm{~kg}$ S/ha as gypsum. Tiwari el al. (2003) report that function of sulphur @ $40 \mathrm{~kg}$ ha'1 gave significantly highest yield of wheat, mustard, rice and chickpea more than rejection sulphur application treatment followed by same level of gypsum in farmers fields. Bandopadhyay and Samui (2000) ${ }^{[7]}$ noticed that gypsum and single superphosphate sources performed better and recorded significantly higher yield and yield attributing characters of groundnut over pyrites. Tomar et al. (2000) noticed that soybean seed yield was increased by application of $25 \mathrm{~kg} \mathrm{~S}$ ha-1, with no further significant increase as the rate was increased up to $75 \mathrm{~kg} \mathrm{~S}$ ha-1. Gokhale et al. (2005) declared that use of sulphur at $40 \mathrm{~kg}$ ha-1 either through gypsum or single super phosphate recorded the higher seed yield, oil, and protein contents of soybean. Wadile et al. (2005) observed that significantly higher sesame seed yield (645 kg ha-1) was obtained when $15 \mathrm{~kg}$ ha-1 of sulphur applied through single super phosphate was applied over the control. 


\section{Effect of levels of sulphur in pulses}

Sita ram kumawat, S. L Yadav, Manoj and M. K. Khistriya (2014) ${ }^{[45]}$ has obtain maximum plant height, leaf area index, number of branches per plant, dry matter content were observed in $30 \mathrm{~kg} \mathrm{~S} / \mathrm{ha}$. With respect to yield attributes and yield the results indicate highest weight of 100 seeds, number of pods, straw yield was found maximum with application of $30 \mathrm{~kg} \mathrm{~S} / \mathrm{ha}$ in green gram. M. Arun Raj, D. vasanthi and M. David Israel, Mani singh (2015) obtained highest growth parameters like plant height, no of leaves per plant, number of branches per plant, total dry matter production and give up attribute like no of seeds per plant, no of pod per plant, thousand seed weight, grain yield were recorded with the application of $30 \mathrm{~kg}$ sulphur along with recommended dose of fertilizer in Green gram. H. R Patel and H. F Patel (2013) ${ }^{\text {[37] }}$ conducted experiment on three levels of sulphur form in gypsum $(0,20,40 \mathrm{~kg} / \mathrm{ha}), 40 \mathrm{~kg} \mathrm{~S} / \mathrm{ha}$ recorded significantly maximum no of branches per plant, plant spread, no of nodules per plant, dry matter per plant, seed yield, protein content as well as highest net realization. Anil kumar patel, Triyuginath, Anurag Prajapati, vivek kumar singh and Saurabh Kumar Pandey (2015) conducted this experiment to evaluate the effect of different level and source of sulphur on growth and yield of black gram. Sulphur sources viz; gypsum, elemental sulphur and ammonium sulphate were used at different levels viz; 0, 20, 40 and $60 \mathrm{~kg} \mathrm{~S} / \mathrm{ha}$ among sources gypsum registered its significant superiority over other sources, with respect of levels of application of $40 \mathrm{~kg} \mathrm{~S} / \mathrm{ha}$ recorded highest growth (plant height, leaf area index, dry matter production, number of branches per plant and also yield components like no of pod per plant and yield. Ravi et al. (2008) conducted a field experiment on Vertisols of Main Agricultural Research Station, Dharwad during rabi season during 2002-03 indicated that application of $30 \mathrm{~kg} \mathrm{~S}$ ha-1 improved the growth parameters like plant height $(114.7 \mathrm{~cm})$, number of leaves (94.5), number of primary branches (14.3), secondary branches (21.2) and dry matter production (3181.4 $\mathrm{kg}$ ha-1) of safflower at harvest over rest of the treatments. Patel et al. (2008) revealed that application of $40 \mathrm{~kg} \mathrm{~S}$ ha-1 recorded significantly higher plant height $(47 \mathrm{~cm})$, plant spread $(41 \mathrm{~cm})$ and branches plant-1 (6) in groundnut over control. Lallu et al. (2008) found that maximum value of LAD (52.2) and LAI (0.93) of Indian mustard were recorded in plants received $60 \mathrm{~kg} \mathrm{~S}$ ha-1 while value of CGR $(7.6 \mathrm{~g} \mathrm{~m}$ 2 day-1) and number of branches (20.3) were noticed maximum in plants fertilized with $40 \mathrm{~kg} \mathrm{~S}$ ha -1 along with RDF. Sarkar et al (2006) Application of different levels of gypsum significantly increased the leaf area index, flower to pod ratio and thereby yield of groundnut and increased further when zinc applied as zinc sulphate along with gypsum. The highest kernel yield was obtained with gypsum application at $750 \mathrm{~kg}$ ha- $1+\mathrm{Zn}$ at $25 \mathrm{~kg}$ ha-1, followed by gypsum at 500 $\mathrm{kg}$ ha- $1+\mathrm{Zn}$ at $25 \mathrm{~kg}$ ha-1. Among the two cultivars, cv. G201 (semi-spreading type) was responsive to gypsum and zinc application and superiority to cv. TMV2 (bunch type) in groundnut crop.

\section{Conclusion}

Sulphur is one of the most important nutrients for growth and development of plant, most of it is present as sulphur containing amino acids (Cysteine, Methionine), glutathione, proteins and sulpholipids in pulses and oilseeds. Use of high analysis fertilizers containing less amount or no sulphur combined with intensive cropping system led to the sulphur deficiencies in plants. Sulphur fertilizers in India are
Bentonite, gypsum, elemental sulphur, pyrites. Sulphur is also present in combinations of nitrogen (ammonium sulphate, ammonium phosphate sulphate), phosphorous (single super phosphate, double super phosphate, triple super phosphate), potassium (potassium sulphate, potassium magnesium sulphate) and micro nutrient fertilizers (copper sulphate, manganese sulphate, zinc sulphate). Optimizing the sulphur availability in appropriate quantities and its synchrony with plant demand increases the yields levels in pulses. Nitrogen, phosphorous, potassium efficiency will be seriously affected under sulphur deficiency. In sulphur deficient soils higher yields, quality and profits are possible only when sulphur application is made as a part of fertilizer application.

\section{References}

1. Ahmad A, Sarfraz A. Screening and partial immunochemical characterization of sulfite oxidase from plant source. Indian Journal of Experimental Biology 2010;48(1):83-86.

2. Arunraj M, Vasanthi D, Manisingh MD. Effect of sulphur on growth and yield of Green gram. International journal of science, environment, and technology. 2018;7(5):1861-1867.

3. Anil D, Sagar GCV, Sreenivas G, Sharma SHK. Effect of sulphur and nitrogen application on growth characteristics and yield of soybean (Glycine max (L.) Merrill). International Journal of Pure and Applied Bioscience 2017;5(4):1548-1554.

4. Anil Kumar Patel, Triyugi N, Anurag P, Vivek KS. Effect of doses and sources of sulphur on growth and yield of Black gram under rain fed condition of vindhyan soil. J. Pharmocognasy and phytochemistry Sp 2018;1:91-94.

5. Banik NC, Senguptha K. Effect of sulphur on growth and yield of green gram. Journal of crop and weed 2012;8(1):109-110.

6. Badruddin M, Karmoker JL. The effect of sulphur deficiency on ion accumulation with special references to $15 \mathrm{~N}$ and $35 \mathrm{~S}$ transport in chickpea. Developments in Plant and Soil Sciences 2001;92:116-117.

7. Bandopadhyay P, Samuai RC. Response of groundnut cultivars to levels and sources of sulphur in west Bengal Indian journal of Agronomy 2000;45(4):761-764.

8. Bohn HL, Barrow NJ, Rajan SSS, Parfitt RL. Reactions of inorganic sulfur in soils. In Tabatabai MA (Ed), Sulfur in Agriculture, Agronomy Monograph, AS A, CSSA, and ISSSA, Madison, WI 1986;27:233-249.

9. Deshbhratar PB, Singh PK, Jambhulkar AP, Ramteke DS. Effect of sulphur and phosphorus on yield, quality and nutrient status of pigeon pea (Cajanus cajan). Journal of Environmental Biology 2010;31(6):933-937.

10. Chandra N, Pandey N. Role of sulfur nutrition in plant and seed metabolism of Glycine max L. Journal of Plant Nutrition 2016;39(8):1103-1111.

11. Degryse F, Ajiboye B, Baird R, Silva RC, McLaughlin MJ. Oxidation of elemental sulfur in granular fertilizers depends on the soil-exposed surface area. Soil Science Society of America Journal 2016;80:294-305.

12. Dhamak AL, Meshram NA, Waikar SL. Comparative studies on dynamics soil properties and forms of sulphur in oilseed growing soils of Ambajogai Tahsil of Beeddistrict. Journal of Agriculture and Veterinary Science 2014;7(12):98-102.

13. Rathour DK, Guptha AK, Choudary RR, Sadhu AC. Effect of integrated phosphorous management on growth 
and yield attributes and yield of summer green gram. The Biascan 2015;10(1):05-07.

14. Fazli IS, Jamal A, Ahmad S, Masoodi M, Khan JS, Abdin MZ. Interactive effect of sulphur and nitrogen on nitrogen accumulation and harvest in oilseed crops differing in nitrogen assimilation potential. J Plant Nutri 2008;31:1203-1220.

15. Gawande SD, Kachhave KG, Kohire OD, Mane SS, Sarvade SG. Effect of different sources and levels of sulphur on nutrient uptake and yield of chickpea. Res. Bull. Marathwada, Agric. Univ 1994;18:48-51.

16. Ganeshamurthy AN, Takkar PN. Integrated use of FYM and $\mathrm{S}$ in soybean-wheat cropping system in relation to substitution of $\mathrm{S}$ in Vertisols of Central India. Australian Journal of Agriculture Research, in press 2000.

17. Germida JJ, Janzen HH. Factors affecting the oxidation of elemental sulfur in soils. Fertilizer research 1993; 35(1, 2):101-114.

18. Giordano M, Pezzoni V, Hell R. Strategies for the allocation of resources under sulfur limitation in the green alga Dunaliella salina. Plant Physiology 2000; 124(2):857-864.

19. Groswami NN. Sulphur in Indian agriculture. In TSI-FAI Symposium, New Delhi (India), 9-11 Mar 1988. Sulphur Institute 1988.

20. Hell R, Hillebrand H. Plant concepts for mineral acquisition and allocation. Current Opinion in Biotechnology 2001;12(2):161-168.

21. Havlin JL, Beaton JD, Tisdale SL, Nelson WL. Sulfur, calcium, and Magnesium. In: Soil Fertility and Fertilizers: An Introduction to Nutrient Management (Indian edition). PHI Learning Private Ltd 2005, 219243.

22. Hermsen C, Koprivova A, Matthewman C, Wesenberg D, Krauss GJ, Kopriva S. Regulation of sulfate assimilation in Physcomitrella patens: mosses are different!. Planta 2010;232(2):461-470.

23. Hosmath JA, Babalad HB, Basavaraj GT, Jahagirdar S, Patil RH, Athoni BK et al. Sulphur nutrition in soybean (Glycine $\max$ (L.) Merril) in India. International Conference on Biological, Civil and Environmental Engineering (BCEE-2014), March 17-18, Dubai (UAE) 2014.

24. Jamal A, Fazli IS, Ahmad S, Abdin MZ, Yun SJ. Effect of sulphur and nitrogen application on growth characteristics, seed and oil yields of soybean cultivars. Korean Journal of Crop Science 2005;50(5):340.

25. Jamal A, Fazli IS, Ahmad S, Abdin MZ. Interactive effect of nitrogen and sulphur on yield and quality of groundnut (Arachis hypogeal L.). 한국작물학회지 2006;51(6):519-522.

26. Jamal A, Moon YS, Zainul Abdin M. Enzyme activity assessment of peanut (Arachis hypogea L.) under slowrelease sulphur fertilization. Australian Journal of Crop Science 2010;4(3):169.

27. Kandpal BM, Chandel AS. Effect of gypsum and pyrite as sources of sulfur on nitrogen-fixation, dry-matter yield and quality of soybean (GLYCINE-MAX). Indian Journal of Agronomy 1993;38(1):137-139.

28. Lewandowska M, Sirk A. Recent advances in understanding plant response to sulfur-deficiency stress. Acta Biochimica Polonica 2008;55(3):457-471.

29. Lucheta AR, Lambais MR. Sulfur in agriculture. Revista Brasileira de Ciênciado Solo 2012;36:1369-1379.
30. McNeill AM, Eriksen J, Bergström L, Smith KA, Marstorp H, Kirchmann $\mathrm{H}$ et al. Nitrogen and sulphur management: challenges for organic sources in temperate agricultural systems. Soil Use and Management 2005; 21(1):82-93.

31. Mitra AK, Banerjee K, Pal AK. Effect of different levels of phosphorus and sulphur on yield attributes, seed yield, protein content of seed and economics of summer greengram. Research on Crops 2006;7(2):404.

32. Bera M, Ghosh GK. Efficacy of sulphur sources on green gram (Vigna radiata l.) in red and lateritic soil of West Bengal (No. RESEARCH) 2015.

33. Mondal MMA, Badruddin M, Malek MA, Hossain MB, Puteh AB. Optimization of sulphur requirement to sesame (Sesamum indicum L.) genotypes using tracer techniques. Bangladesh Journal of Botany 2012;41(1):713.

34. Niraj VPS, Ved P. Effect of phosphorus and sulphur on growth, yield and quality of blackgram (Phaseolus mungo L.). Asian Journal of Soil Science 2014;9(1):117120.

35. Ostrowska D, Pietkiewicz S, Cieslinski M, Kucinska K, Gozdowski D. Biomass accumulation and absorption of photosynthetic active radiation by rapeseed plants depending on sulphur fertilization. World J Agricult Sci 2008;4:133-136.

36. Paliwal AK, VajpaI SK, Kiran V. Interaction effect of sulphur and phosphorus application on yield and major nutrient composition of soybean (Glycine max L. Merrill) grown on alfisol. Asian Journal of Soil Science 2009;4(1):113-117.

37. Patel HR, Patel HF, Maheriya VD, Dodia IN. Response of kharif greengram (Vigna radita L. Wilczek) to sulphur and phosphorus fertilization with and without biofertilizer application. The bioscan 2013;8(1):149-152.

38. Sisodiya RR, Barbaria NB, patel HP, Bambhrolis P. Sulphur fertilization in groundnut under calcareious oil conditions. Effects on nutrient uptake content and yield. The Basin 2016;11(4):2393-2397

39. Sabir M, Hanafi MM, Hakeem KR. Sulfur nutrition of oil palm for enhancing oil yield in tropics. In Crop Production and Global Environmental Issues (Springer, Cham 2015, 349-368.

40. Saito K. Sulfur assimilatory metabolism. The long and smelling road. Plant Physiology 2004;136:2443-2450.

41. Saha S, Saha M, Saha AR, Mitra S, Sarkar SK, Ghorai AK et al. Interaction effect of potassium and sulfur fertilization on productivity and mineral nutrition of sunnhemp. Journal of plant nutrition 2013;36(8):11911200.

42. Singh Shivay Y, Prasad R, Pal M. Effect of levels and sources of sulfur on yield, sulfur and nitrogen concentration and uptake and S-use efficiency in basmati rice. Communications in soil science and plant analysis 2014;45(18):2468-2479.

43. Shilpi S, Nuruzzaman MD, Akhter F, Islam MN, Sutradher GNC. Response of nitrogen and sulfur on the oil content of sesame and nutrient status of soil. International Journal of Bio-resource and Stress Management 2014;5(1):041-046.

44. Singh SP, Yogesh K, Sonu Singh. Effect of sulphur on yield, quality uptake of nutrients in Green gram. Annals of plant and soil research 2012;19(2):143-147 (2017) 14.

45. Kumawat SR, Khistriya MK, Yadav SL, Manoj K. Effect of sulphur and phosphorus on growth and yield attributes 
on summer green gram [Vigna radiata (L.) Wilczek]. International Journal of Agricultural Sciences 2014;10(2):770-773.

46. Singh SK, Dey P, Singh S, Sharma PK, Singh YV, Latare AM et al. Emergence of boron and sulphur deficiency in soils of Chandauli, Mirzapur, Sant Ravidas Nagar and Varanasi districts of Eastern Uttar Pradesh. Journal of the Indian Society of Soil Science 2015;63(2):200-208.

47. Singh S, Kumar P. Soil fertility status of vegetables growing area of Varanasi and pulses growing area of Mirzapur. Journal of the Indian Society of Soil Science, 2012;60(3):233-236.

48. Singh S, Sarkar D, Bhudevi M, Rakesh S, Singh RK, Kar $\mathrm{S}$ et al. Advanced Forms of Sulphur Formulations for Improving Use Efficiency in Crop Species. Annual Research \& Review in Biology 2018, 1-14.

49. Singh MV. Importance of sulphur in balanced fertilizer use in India. Fertiliser News 2001;46(10):13-36.

50. Tandon HLS. Soil sulphur deficiencies: towards integration of diverse data bases. Indian Journal of Fertilisers 2010;6(10):14-20.

51. Takahashi H. Regulation of sulfate transport and assimilation in plants. In International review of cell and molecular biology Academic Press 2010;281:129-159.

52. Tiwari KN, Gupta BR. Sulphur for sustainable high yield agriculture in Uttar Pradesh. Indian Journal of Fertilisers 2006;1(11):37.

53. Tripathi N. Role of FCO in promoting quality secondary and micronutrients. Fertiliser News 2003;48(4):111-114.

54. Tripathi PK, Singh MK, Singh JP, Singh ON. Effect of rhizobial strains and sulphur nutrition on mungbean (Vigna radiata (1.) wilczek) cultivars under dryland agroecosystem of Indo-Gangetic plain. African Journal of Agricultural Research 2012;7(1):34-42.

55. Varin S, Cliquet JB, Personeni E, Avice JC, LemauvielLavenant S. How does sulphur availability modify $\mathrm{N}$ acquisition of white clover (Trifolium repens L.)? Journal of Experimental Botany 2010;61(1):225234.

56. Vidyalakshmi R, Paranthama R, Bhakyaraj R. Sulphur Oxidizing Bacteria and Pulse Nutrition- A Review. World Journal of Agricultural Sciences, 2009;5(3):270-278.

57. Yoshimoto N, Inoue E, Saito K, Yamaya T, Takahashi H. Phloem-localizing sulfate transporter, Sultr1; 3, mediates re-distribution of sulfur from source to sink organs in Arabidopsis. Plant Physiology 2003;131(4):1511-1517. 